\title{
REPELLENT EFFECT OF CERTAIN CHEMICALS COMPOUNDS ON WILD BIRDS ATTACKING WHEAT AND COWPEA UNDER FIELD CONDITIONS
}

\author{
Mohamed A. Issa*, M.I.A. El-Bakhshawngi and M.H.E. Lokma \\ Plant Prot. Res. Inst., Agric. Res. Cent., Dokki, Giza, Egypt
}

Received: 21/04/2019; Accepted: 09/07/2019

\begin{abstract}
The efficacy of Tukam ${ }^{\circledR}$ and VP Skud ${ }^{\circledR}$ compounds were tested as repellents against wild birds attacking wheat and cowpea fields in Sharkia Governorate. In the wheat crop experiment, the house sparrow Passer domesticus niloticus attacked the spikes with the highest percentage of damage $(14.82 \%)$ in the control trial, during the $6^{\text {th }}$ week when spikes emergence. While damage percentages were $11.19,9.22,8.94$ and $8.73 \%$ when applying Tukam ${ }^{\circledR}$ concentrations of 2.5, 5,10 and $15 \mathrm{ml} /$ liter, respectively during the same period in the treatment trials. The highest protection percentage was obtained in the $4^{\text {th }}$ week with $15,10,5$ and $2.5 \mathrm{ml} / \mathrm{liter}$, respectively. The same trend was found with VP Skud®, since the highest percentages of damage were $10.07 \%, 9.16 \%$, $8.08 \%$ and $6.20 \%$ in the $6^{\text {th }}$ week with the four concentrations $1,2,4$ and $6 \mathrm{ml} /$ liter, respectively. While the protection percentage were the highest during the $4^{\text {th }}$ week with concentrations of $6,4,2$ and $1 \mathrm{ml} /$ liter, respectively. In the cowpea experiment, pigeon (Cloumba sp.) attacked the pods and caused high percentage of damage reached $13.32 \%$ in the $5^{\text {th }}$ week of the control trial. When spraying Tukam ${ }^{\circledR}$ at a concentration of $15.0 \mathrm{ml} /$ liter, the damage was dropped considerably as compared with other concentrations or control after pollination. The decrease in damage was found to be $2.11,3.88$, 4.74 and $7.38 \%$, after the $2^{\text {nd }}, 3^{\text {rd }}, 4^{\text {th }}$ and $5^{\text {th }}$ week, respectively. The highest protection percentage was recorded with the concentration of $15 \mathrm{ml} /$ liter. The same trend was recorded with VP Skud®. It gave the lowest percentage of damage at the concentration of $6 \mathrm{ml} / \mathrm{liter}$ with values of 1.97, 3.21, 5.67 and $10.56 \%$, during the $2^{\text {nd }}, 3^{\text {rd }}, 4^{\text {th }}$ and $5^{\text {th }}$ week after pollination, respectively. Protection percentage reached its maximum during the study period with the concentration of $6 \mathrm{ml} / \mathrm{liter}$.
\end{abstract}

Key words: Wild birds, damage, crop depredation, repellent effect, wheat, cowpea, tukam®, VP. Skud®.

\section{INTRODUCTION}

Most bird species are beneficial but some species can seriously cause severe damages to many important agricultural crops in many countries. In Egypt, wild bird species are attacking various economic important crops (Issa and El-Bakhshawngi, 2018). Bird damage varies according to the field site, crop type, region and mainly to bird species in any specific area (Ahmad et al., 2018). Wheat consumption in Egypt is increasing during the recent years as a result of the fast growing of human population. Therefore, the need to increase crop yields and/or decrease losses to birds is very essential at the present time and in

\footnotetext{
*Corresponding author: Tel. : +2001005744943

E-mail address: mohamedelbkh@gmail.com
}

the near future. Crop losses due to bird pests are a major threat to food security. One of the most common bird pest of wheat crop is the house sparrow, Passer domesticus niloticus, which attack wheat plants, starting from the second week after pollination and during the repining stage (Attia, 2013). El-Deeb (1991) mentioned that bird damage starts from the early ripening stage, increases during the milky and dough stages and reaches their maximum at the mature stage.

Cowpea is a member of the Leguminosae family. It is economically important warm season grain, and a major source of dietary protein and considered as a dependable commodity that produces income for farmers 
(Langyintuo et al., 2003). Pigeons and house sparrow consume and contaminate large quantities of food destined for human including Cowpea. Blue rock pigeon, Columba livia, damage $42 \%$ of the peas crop either chickpeas or pigeon peas (Kale et al., 2014).

Chemical repellents are intended to prevent birds from feeding on a particular food. There is a necessity to use avicide compounds to control bird populations and thus decrease their damage to crops. The mode of action of avicides depends on the chemical used. Some avicides may be used as bird repellents, some were selectively toxic to birds. Some have been used as soporifics and some as reproductive inhibitors (Schafer, 1991). Chemical repellents are intended to prevent birds from feeding on a particular food. Methiocarb is one of the avicides used as bird control agent, which provide alternative means of reducing bird damage applied to grain sorghum. Grain yields were higher and bird damage was lower on the methiocarb-treated plots than on the check plots (Duncan, 1980). The methiocarb grain bait at $0.1 \%$ proved to be highly effective in repelling sparrows and may function as an ideal crop protection against bird invasion (Rizvi et al., 2002). Methyl anthranilate, formulated as Bird Shield ${ }^{\circledR}$ repellent was effective to protect sweet corn, sunflower and cherries against bird depredation (Askham, 2000). Polyphenols with several aspects related to phenolics chemistry convert to the several compounds as coumarins, tannins, anthocyanins, cinnamic acids and flavonoids (Pereira et al., 2009). Phenolic compound and terpenes are plant secondary metabolites that act as deterrents for gallinaceous birds feeding and Canada geese (Bryant and Kuropat, 1980; Buchsbaum et al., 1984). Generally, the present work was designed to study the repellency effect of two different chemical compounds, Tukam ${ }^{\circledR}$ (Magnesium oxide 5\% $W / W$ ) and VP Skud® $\left(\mathrm{K}_{2} \mathrm{O} 10 \% \mathrm{~W} / \mathrm{W}\right.$ and sylvinite and polyphenolic), at different concentrations, on reducing bird damage to wheat and cowpea crops under field conditions.

\section{MATERIALS AND METHODS}

\section{Study Areas}

The experiments were carried out at Sharkia Governorate, Egypt, in two locations:

\section{El-Qurein $\left(30^{\circ} 60^{\prime} \mathrm{N}, 31^{\circ} 74 ' \mathrm{E}\right)$}

Fields cultivated with wheat crop were chosen at this location according to farmers' complaints of bird depredation. The selected plots occupy more than 20 faddans during the wheat growing season of 2017. The area boundaries are drainage canal from the East with several shrubs, small water canal from the West with dense shrubs, several dominant tree species from the North including Ficus sp. and camphor tree, Cinnamomum camphora, with a pass way and to the South another pass way followed by fields cultivated with vegetable crops.

\section{El-Qanayat $\left(30^{\circ} 62^{\prime} \mathrm{N}, 3^{\circ} 46^{\prime} \mathrm{E}\right)$}

The study area occupies about 20 faddans cultivated with cowpea during the season of 2017. This area has a history of severe bird attack. The borders were as follows: In the East, fields cultivated with maize; the West, a pass way exists then maize fields; a small water canal with dense shrubs and mulberry trees (Morus sp.) from the North and to the South a pass way exists followed by maize fields.

\section{Tested compounds}

\section{Tukam®}

- Common name: Magnesium oxide 5\% W/W.

- Trade name: Tukam ${ }^{\circledR}$ was obtained from Shoura Chemicals Products, Egypt. The experimental concenterations applied in this work were $2.5,5.0,10.0$ and $15.0 \mathrm{ml} /$ liter, the normal recommendation concentration was 5 $\mathrm{ml} / \mathrm{liter}$.

\section{VP Skud ${ }^{\circledR}$}

- Common name: $\mathrm{K}_{2} \mathrm{O} 10 \% \mathrm{~W} / \mathrm{W}$ and sylvinite and polyphenolic

- Trade name: VP Skud® was obtained from Gaara Seeds Company, Egypt. The recommendation concentration was $2-4 \mathrm{ml} /$ 
liter, the experimental concentrations applied in this work were 1, 2, 4 and $6 \mathrm{ml} /$ liter.

\section{Wheat (Triticum aestivum) Experiments:}

Nine plots about 2 faddans for each plot were selected for treatments and separated by $100 \mathrm{~m}$. The above mentioned concentrations of Tukam ${ }^{\circledR}$ and VP Skud ${ }^{\circledR}$ were initially used at the milky stage of wheat. The first application was made in the second week after pollination (milky stage), while the second one was applied 15 days after accomplished the first application. The treated and untreated plots were inspected weekly from the end of the second week after pollination till harvest to determine the damage caused by house sparrow (Passer domesticus niloticus). Damage assessment was carried out using the methods and calculations of Poche et al. (1982). A wooden square frame (50 X 50 $\mathrm{cm}$ ) was used for sampling. Twenty randomly samples were examined for each plot. The number of damaged and undamaged spikes found within the frame was recorded weekly till harvest.

The percentage damage to each spike was scored according to the following categories (De-Haven, 1974):

- Category $1=10 \%$ level (1-20\% damage).

- Category $2=30 \%$ level (21-40\% damage).

- Category $3=50 \%$ level (41-60\% damage).

- Category $4=70 \%$ level (61-80\% damage).

- Category 5=90\% level (81-100\% damage).

Percentage of damage was calculated as follow:

$$
\text { Damage }(\%) \frac{\mathrm{C} X 100}{\mathrm{~T}}
$$

Where:

$\mathrm{C}=$ undamaged $\times 0.0+10 \%$ damage $\times 0.1+$ $30 \%$ damage $\mathrm{x} 0.3+50 \%$ damage $\mathrm{x} 0.5+70 \%$ damage $\times 0.7+90 \%$ damage $\times 0.9 ; \mathrm{T}=$ Total investigated heads.

\section{Cowpea (Vigna unguiculata) Experiments:}

The same concentrations of Tukam ${ }^{\circledR}$ and VP Skud ${ }^{\circledR}$ which were applied in wheat, were also applied in the repining stage of cowpea with the same procedure. The first application was performed at the end of first week of flowering stage and the second spray was executed after fifteen days of the first application. The treated and control plots were inspected weekly from the end of second week of flowering till harvest to determine the percentage of damage. The same execution was as in wheat experiments. Determination percentage of damage by pigeon (Cloumba sp.) for cowpea plants was carried out after pollination at pods formation stage. Five randomly samples were taken weekly in fields treated and untreated (control). In each sample ten successive plants were inspected to estimate the degree of damage in ripening stage according to Issa and El-Bakhshawngi (2018). The percentage of damage was calculated by the formula:

Damage $(\%)=$

$$
\frac{\text { No. of damaged pods }}{\text { Total No. of examined pods }} \times 100
$$

\section{The Percentage of protection}

Protection percentage was calculated according to Khattab (1993) and El-Sherbiny et al. (1994) by the formula:

Protection $(\%)=$

Damage in control $(\%)$ - Damage in treatment $(\%)$

Damage in control $(\%)$

\section{Data Analysis}

Data were arranged using excel sheet and statistically analyzed using the (CoStat Statistical Software, 2005). All data were first subjected to one-way analysis of variance (ANOVA) and least significant differences (LSD) were calculated at $\mathrm{P} \leq 0.05$.

\section{RESULTS AND DISCUSSION}

\section{Wheat Experiments}

\section{Tukam ${ }^{\circledR}$ experiment:}

Results in Table 1 demonstrate that the damage percentage of wheat increased in treated and control fields throughout the $1^{\text {st }}$ week after pollinations and during grains development till the $6^{\text {th }}$ week. The highest percentage of damage was recorded during the $6^{\text {th }}$ week of control 
$(14.82 \%)$. Damage percentage for the following concentrations of $2.5,5,10$ and $15 \mathrm{ml} /$ liter were $11.19 \%, 9.22 \%, 8.94 \%$ and $8.73 \%$, respectively.

The lowest damage percentage was $1.72 \%$, $1.68 \%, 1.45 \%$ and $1.38 \%$ for the same concentrations, respectively. Highly significant differences were observed among the four different concentrations and control in the $3^{\text {rd }}$ till the $6^{\text {th }}$ week, while there were no significant differences in the $2^{\text {nd }}$ week.

Results in Fig. 1 reveal that no protection was found during the $2^{\text {nd }}$ week, after the first spray with Tukam ${ }^{\circledR}$ with concentrations of 2.5 and $5 \mathrm{ml} /$ liter. On the other hand, the $4^{\text {th }}$ week gave the highest values of protection percentage in descending order with concentrations $(15,10,5$ and $2.5 \mathrm{ml} /$ liter).

\section{VP Skud ${ }^{\circledR}$ experiment}

The VP Skud® compound was investigated with four concentrations (1, 2, 4 and $6 \mathrm{ml} /$ liter), with the same procedures used with Tukam ${ }^{\circledR}$. The results in Table 2 clear that the percentage of wheat damage was increased gradually throughout the weeks at all concentrations, with low value $0.61 \%$ at concentration of $6 \mathrm{ml} / \mathrm{liter}$ during the $2^{\text {nd }}$ week. The highest percentage of damage was $14.82 \%$ and the lowest was $6.20 \%$ during the $6^{\text {th }}$ week with control and $6 \mathrm{ml} /$ liter concentration, respectively. Highly significant differences were found among all the treatments and control.

Results in Figs. 2 and 3 reveal that among all the treatments the concentration of $6 \mathrm{ml} / \mathrm{liter}$ was the best in protection percentage from the $2^{\text {nd }}$ till the $6^{\text {th }}$ weeks. The same trends were observed with Tukam ${ }^{\circledR}$, the $4^{\text {th }}$ week give the highest value of protection percentage too in descending order with concentrations $(6,4,2$ and $1 \mathrm{ml} /$ liter, respectively).

These result agree with El-Deeb (1990) who found that Mesurol has better repellency effect on wheat than on other crops. Kattab (1993) cleared that house sparrow attacks wheat at ripening stage and the damage varied from location to location depending on the prevailing agroecosystem and weather conditions. He added that house sparrow avoided the chemicals which applied at higher concentrations. Also the protection indices of Nuvacron at the concentration of $0.5 \%$ were from 72.8 to 76.7 and at concentration of $1.0 \%$ from 81.9 to 89.7 . Askham (2000) stated that birds in sunflowers didn't go a way after the crop had been treated and a little feeding on crop was noted, considerably less or no damage was found in comparison with the untreated fields. Mesaroal treated fields received less damage than control plot was observed by Kassa and Jackson (1979). About $38-100 \%$ feeding repellency among horned larks offered wheat seeds (Triticum spp.) treated with 168-3010 ppm anthraquinone during the concentration-response were observed by Werner et al. (2015). In New Zeland, Day et al. (2012) found that the free ranging house sparrow (Passer domesticus) responded to various concentrations of repellent (Avex) with treated wheat, the highest concentration (2\%) reduced wheat consumption. Hess and Britton (1997) found that feeding hens on magnesium oxide reduced feed consumption and decreased egg production.

\section{Cowpea Experiments}

\section{Tukam ${ }^{\circledR}$ experiment}

The obtained results in Table 3 reveal that the highest consumed percentage of cowpea pods were recorded with control treatment $13.32 \%$, followed by the concentration of 2.5 $\mathrm{ml} /$ liter with $11.53 \%$ in the $5^{\text {th }}$ week. The concentrate of $15 \mathrm{ml} /$ liter gave the lowest percentage of damage compared to other concentrations and control during the different weeks with values of $2.11,3.88,4.74$ and $7.38 \%$ in the $2^{\text {nd }}, 3^{\text {rd }}, 4^{\text {th }}$ and $5^{\text {th }}$ week, respectively. Statistical analysis of data showed that there were no significant differences among different concentrations and control in the $2^{\text {nd }}$ week. On the other hand, there were significant differences in the $3^{\text {rd }}, 4^{\text {th }}$ and $5^{\text {th }}$ week.

Results in Fig. 4 show that the pigeons consumed more of cowpea beans with the concentration of $2.5 \mathrm{ml} /$ liter from Tukom ${ }^{\circledR}$ during the $2^{\text {nd }}$ and $5^{\text {th }}$ week. The highly protection percentage were recorded with concentrations of 15 and $10 \mathrm{ml} /$ liter, during the whole period. 
Table 1. Damage percentage caused by house sparrow as influenced by repellent effect of Tukom ${ }^{\circledR}$ in wheat fields at El-Qurein location, Sharkia Governorate during 2017 season

\begin{tabular}{lccccc}
\hline Concentration & $\mathbf{2}^{\text {nd }}$ week & $\mathbf{3}^{\text {rd }}$ week & $\mathbf{4}^{\text {th }}$ week & $\mathbf{5}^{\text {th }}$ week & $\mathbf{6}^{\text {th }}$ week \\
\hline $\mathbf{2 . 5} \mathbf{~ m l / l i t e r ~}$ & 1.72 & 2.76 & 4.79 & 8.24 & 11.19 \\
$\mathbf{5} \mathbf{~ m l} /$ liter & 1.68 & 2.58 & 3.43 & 7.25 & 9.22 \\
$\mathbf{1 0 ~} \mathbf{~ m l} /$ liter & 1.45 & 2.23 & 3.15 & 6.99 & 8.94 \\
$\mathbf{1 5} \mathbf{~ m l} /$ liter & 1.38 & 1.98 & 3.06 & 6.5 & 8.73 \\
$\mathbf{C o n t r o l}$ & 1.68 & 3.04 & 5.73 & 9.89 & 14.82 \\
$\mathbf{L S D ~ 0 . 0 5}$ & $\mathrm{NS}$ & $0.47^{* *}$ & $0.46^{* *}$ & $0.97 * *$ & $0.68^{* *}$ \\
\hline
\end{tabular}

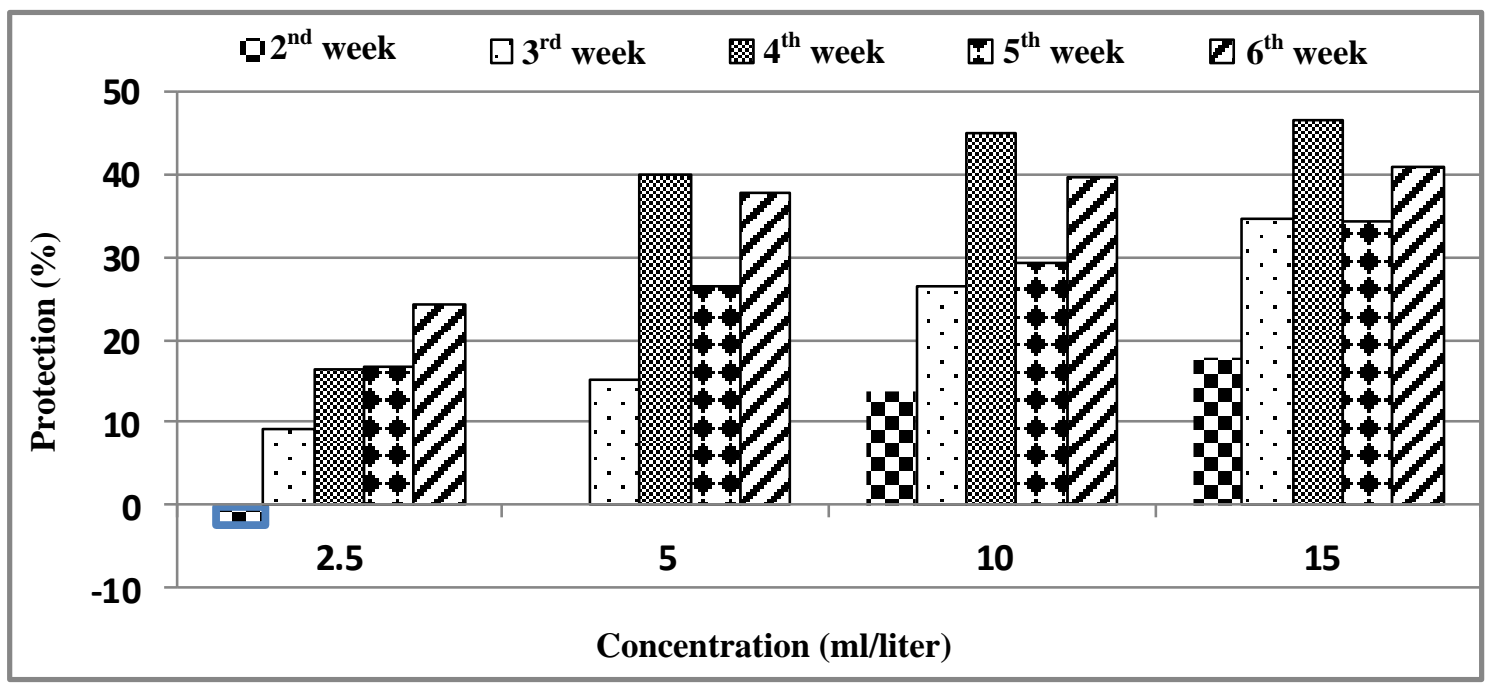

Fig. 1. The protection percentage of Tukam ${ }^{\circledR}$ compound in wheat fields attacked by house sparrow at El-Qurein location during 2017 season

Table 2. Damage percentage caused by house sparrow as influenced be repellent effect of VP Skud $®$ in wheat fields at El-Qurein location, Sharkia Governorate during 2017 season

\begin{tabular}{|c|c|c|c|c|c|}
\hline Concentration & $2^{\text {nd }}$ week & $3^{\text {rd }}$ week & $4^{\text {th }}$ week & $5^{\text {th }}$ week & $6^{\text {th }}$ week \\
\hline $1 \mathrm{ml} /$ liter & 0.87 & 2.20 & 3.09 & 6.66 & 10.07 \\
\hline $2 \mathrm{ml} / \mathrm{liter}$ & 0.76 & 1.88 & 2.46 & 5.87 & 9.16 \\
\hline $4 \mathrm{ml} / \mathrm{liter}$ & 1.23 & 1.60 & 2.13 & 5.19 & 8.08 \\
\hline $6 \mathrm{ml} / \mathrm{liter}$ & 0.61 & 1.09 & 1.43 & 4.41 & 6.20 \\
\hline Control & 1.68 & 3.04 & 5.73 & 9.89 & 14.82 \\
\hline LSD 0.05 & $0.49 * *$ & $0.27 * *$ & $0.46^{* *}$ & $0.73 * *$ & $0.56 * *$ \\
\hline
\end{tabular}




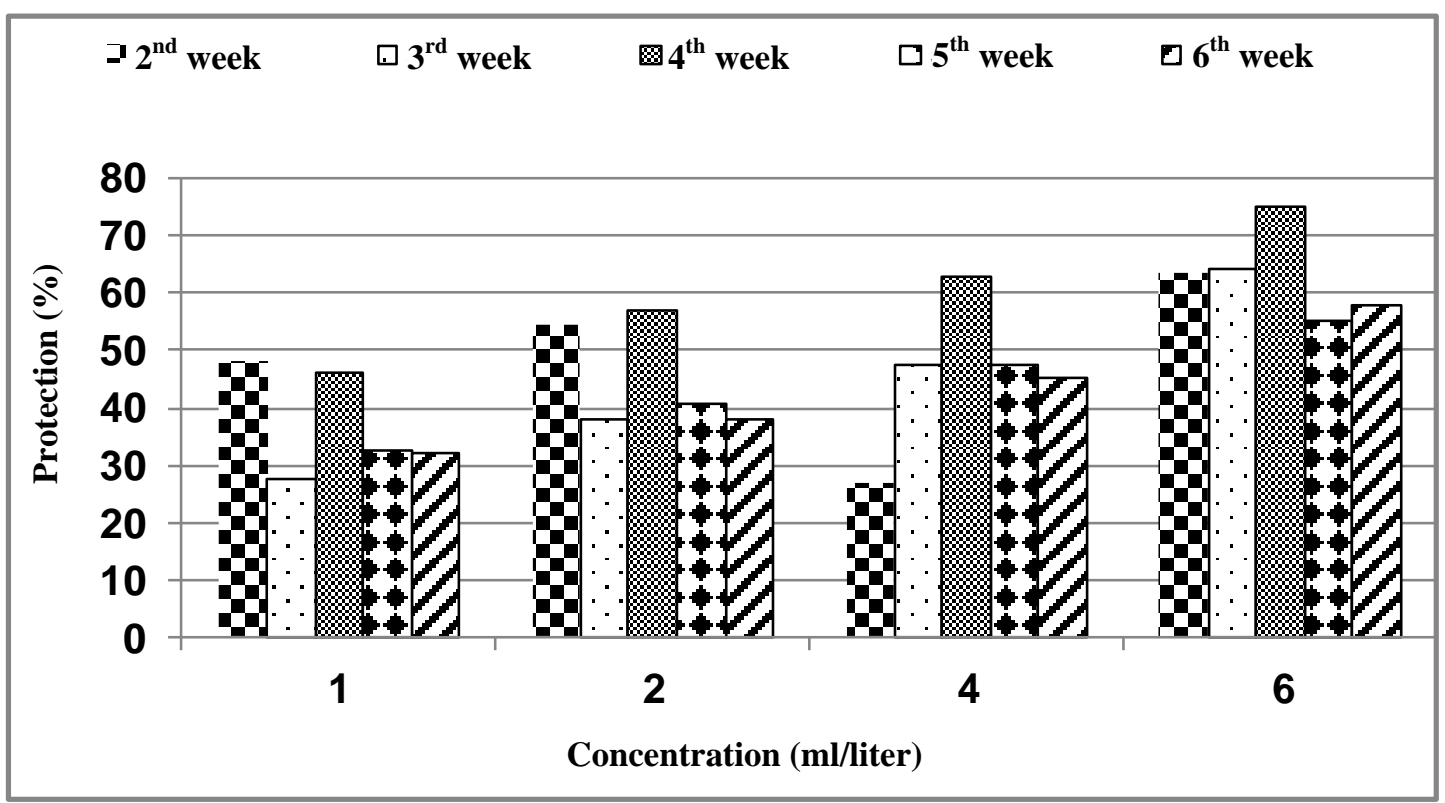

Fig. 2. The protection percentage of VP Skud ${ }^{\circledR}$ compound in wheat fields attacked by house sparrow at El-Qurein location during 2017 season

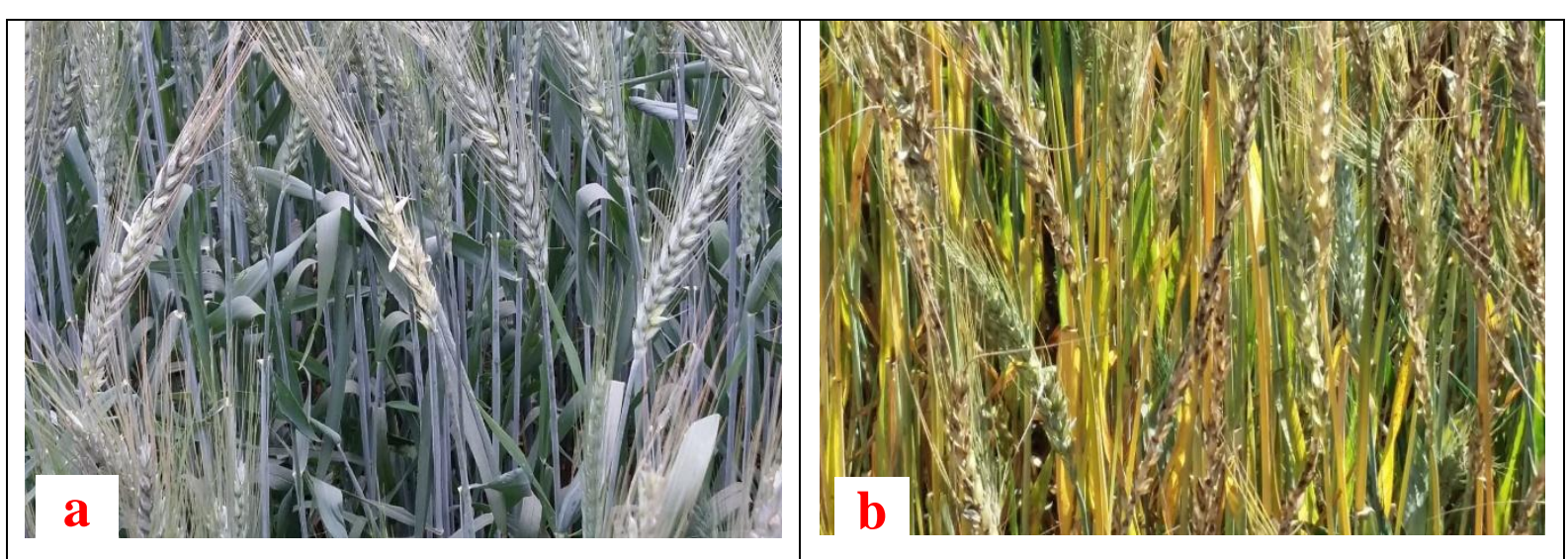

Fig. 3. Damage caused by house sparrow in wheat spikes, a: early damage, b: late damage

Table 3. Damage percentage caused by pigeon (Cloumba sp.) to cowpea fields as influenced by repellent effect of Tukom ${ }^{\circledR}$ at El-Qanayat location, Sharkia Governorate during 2017 season

\begin{tabular}{lcccc}
\hline Concentration & $\mathbf{2}^{\text {nd }}$ week & $\mathbf{3}^{\text {rd }}$ week & $\mathbf{4}^{\text {th }}$ week & $\mathbf{5}^{\text {th }}$ week \\
\hline $\mathbf{2 . 5} \mathbf{~ m l / l i t e r ~}$ & 2.7 & 4.22 & 6.79 & 11.53 \\
$\mathbf{5} \mathbf{~ m l} /$ liter & 2.52 & 4.02 & 5.99 & 10.28 \\
$\mathbf{1 0} \mathbf{~ m l} /$ liter & 2.25 & 3.91 & 5.09 & 8.76 \\
$\mathbf{1 5} \mathbf{~ m l} /$ liter & 2.11 & 3.88 & 4.74 & 7.38 \\
$\mathbf{C o n t r o l}$ & 3.09 & 5.33 & 9.47 & 13.32 \\
$\mathbf{L S D ~ 0 . 0 5}$ & $\mathrm{NS}$ & $1.02^{*}$ & $1.51^{* *}$ & $1.13^{* *}$ \\
\hline
\end{tabular}




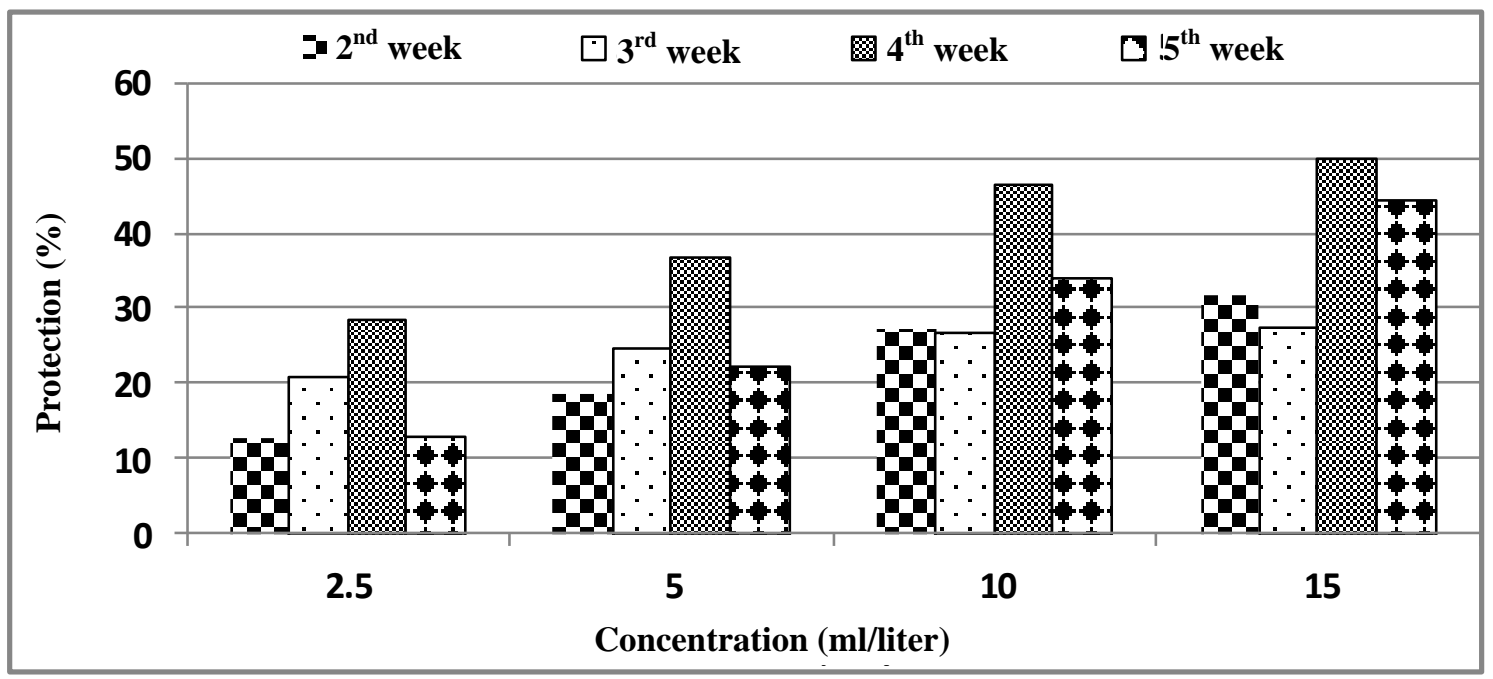

Fig. 4. The protection percentage of Tukom ${ }^{\circledR}$ compound to cowpea fields attacked by pigeon (Cloumba sp.) at El-Qanayat location during season of 2017

\section{VP Skud ${ }^{\circledR}$ experiment}

Results clearly showed that, spraying of VP Skud® was not effective to prevent birds depredate cowpea in the concentration of $1 \mathrm{ml} /$ liter at the $2^{\text {nd }}$ week, while it was effective with concentration of $6 \mathrm{ml} / \mathrm{liter}$ at the same week. The highest percentage of damage in the control and different treatments 1, 2, 4 and 6 $\mathrm{ml} /$ liter and were at $5^{\text {th }}$ week with $13.32,12.13$, $12.6,11.35$ and $10.56 \%$, respectively. The statistical analysis illustrated significant variations between treatments in the different weeks (Table 4).

Results in Figs. 5 and 6 cleared that the concentration of $1 \mathrm{ml} /$ liter was not affective in protect the crop at the $2^{\text {nd }}$ week. But the concentration of $6 \mathrm{ml} / \mathrm{liter}$ gave the highest percentage of protection during the whole period of the study.

Pigeon and house sparrow can be considered a menace when seeds have been formed in the pods. They start feeding on the seeds from the time pods are being formed until harvest. At the pod filling stage, they can completely devour the crop. Harvesting pods must be carried out as soon as they mature before the crop is too dry because they shattered easily and scatter the seeds on the ground.

For discussing the aforementioned results it could be concluded that the effectiveness of the tested compounds differed considerably according to the type of chemical, concentrations, crops, its stage and type of habitat. Kattab (1993) cleared that wild birds attack broad bean and peas at old land and newly reclaimed area with mean percentage of damage reached $14.4 ; 11.1$ and $11.1 ; 9.5$, respectively. Also, the protection indices of Nuvacron at concentration of $0.5 \%$ were ranged from 69.8 to $76.2 \%$, concentration of $1.0 \%$ from 76.7 to 84.8 and Dimethoate concentration of $0.5 \%$ were from 60.7 to $67.3 \%$ and concentration of $1.0 \%$ from 63.8 to $71.2 \%$, while Marshal concentration of $0.5 \%$ were from 68.0 to $72.5 \%$ and concentration of $1.0 \%$ from 74.0 to $76.1 \%$. York et al. (2000) recorded horned lark damage to lettuce seedlings with $60 \%$ in Anthraquinone treated and 20\% in Mesurol treated, while control plot $100 \%$ at enclosure. Cummings et al. (2006) referred that horned larks consumed fewer lettuce seedlings treated with flight control (anthraquinone) than untreated seedlings. Birds consumed $8.5 \%$ seedlings in the treated enclosures, versus $68.5 \%$ seedlings in untreated enclosures. Niner $\boldsymbol{e t}$ al. (2015) mentioned that the effect of repellent range from quick aversion upon contact with taste and smell receptors to delayed gastrointestinal discomfort and vomiting following ingestion after suffering the negative sequence of a repellent, birds usually forage elsewhere. 
Table 4. Damage percentage caused by pigeon (Cloumba sp.) to cowpea fields as influenced by repellent effect of VP Skud ${ }^{\circledR}$ at El-Qanayat location, Sharkia Governorate during 2017 season

\begin{tabular}{|c|c|c|c|c|}
\hline Concentration & $2^{\text {nd }}$ week & $3^{\text {rd }}$ week & $4^{\text {th }}$ week & $\overline{5^{\text {th }} \text { week }}$ \\
\hline $1 \mathrm{ml} /$ liter & 3.49 & 4.31 & 7.83 & 12.13 \\
\hline $2 \mathrm{ml} / \mathrm{liter}$ & 2.28 & 4.07 & 7.79 & 12.6 \\
\hline $4 \mathrm{ml} /$ liter & 2.02 & 3.96 & 6.22 & 11.35 \\
\hline $6 \mathrm{ml} /$ liter & 1.97 & 3.21 & 5.67 & 10.56 \\
\hline Control & 3.09 & 5.33 & 9.47 & 13.32 \\
\hline LSD 0.05 & $0.75^{* *}$ & $1.30^{*}$ & $1.49 * *$ & $0.96 * *$ \\
\hline
\end{tabular}

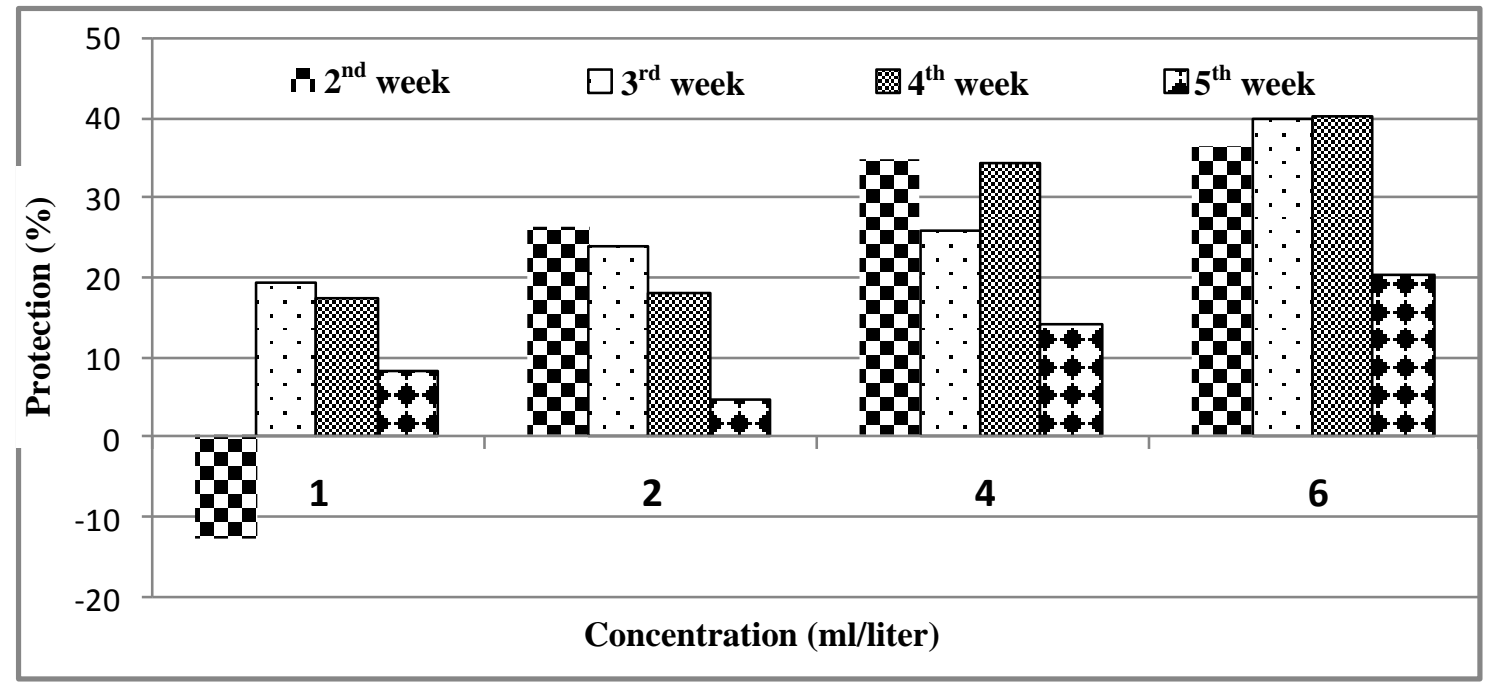

Fig. 5. The protection percentage of VP Skud ${ }^{\circledR}$ compound to cowpea fields attacked by pigeon (Cloumba sp.) at El-Qanayat location during season of 2017

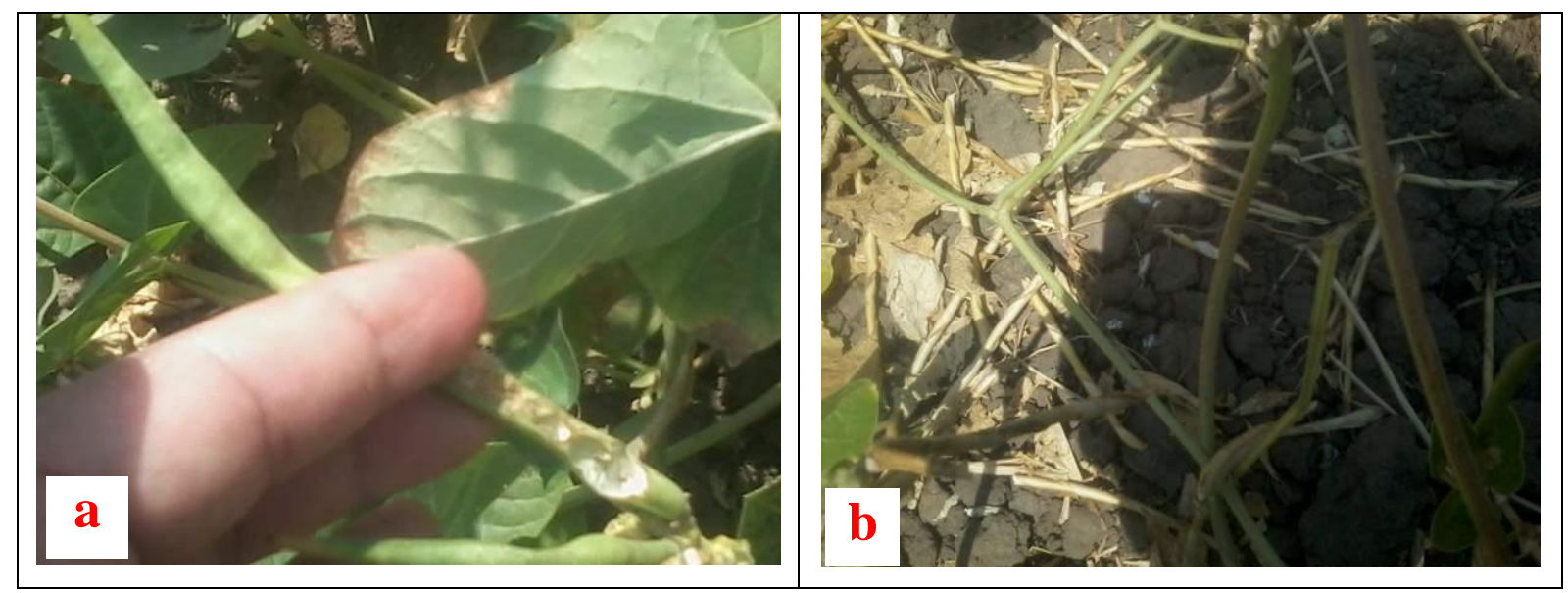

Fig. 6. Damage caused by pigeon in cowpea pods, a: early damage, b: late damage 


\section{REFERENCES}

Ahmad, S., Z. Saleem, F. Jabeen, B. Hussain, T. Sultana, S. Sultana, K.A. Al-Ghanim, N.M.A. Al-Mulhim and S. Mahboobs (2018). Potential of natural repellents methylanthranilate and anthraquinone applied on maize seeds and seedlings against house sparrow (Passer domesticus) in captivity. Braz. J. Biol., 78 (4): 667-672.

Askham, L.R. (2000). Efficacy of the aerial application of methyl anthranilate in reducing bird damage to sweet corn, sunflowers, and cherries. In: Proc. Vertebrate Pest Conf. TP Salmon and AC Crabb, Eds. Davis: Univ. California., 19: 22-25.

Attia, M.A.I. (2013). Studies on some wild bird species at Ismailia Governorate. Ph.D. Thesis, Fac. Agric., Al-Azhar Univ., 205.

Bryant, J. and Kuropat, P. (1980). Feeding selection by subarctic browsing vertebrates. Ann. Rev. Ecol. Syst., 11: 261-285

Buchsbaum, R., I. Valiela and J.M. Teal (1984). The role of phenolic compounds and other plant constituents in feeding by Canada geese in a coastal marsh. Oecologia, $63: 343-349$.

CoStat statistical software (2005). Microcomputer program analysis version 6.311. Cohort Software, Monterey California, USA.

Cummings, J.L., D.L. York, T.M. Primus, R.M. Engeman and R.E. Mauldin (2006). Effectiveness of flight control to reduce damage to lettuce seedlings from horned larks. Proc Vertebr Pest Conf., 22 : 225-227.

Day, T.D., B.K. Clapperton, R.E.R. Porter, J.R. Waas and L.R. Matthews (2012). Responses of free-ranging house sparrows to feed containing primary and secondary repellents. NZ J. Crop Hort. Sci., 40 : 127-138

De-Haven, R.W. (1974). Bird damage appraisal methods in some agriculture crops. Proc. $6^{\text {th }}$ Vert. Pest Cont., 246-248.

Duncan, R.R. (1980). Methiocarb as a bird repellent on ripening grain sorghum. Can. J. Plant Sci., 60: 1129-1133.

El-Deeb, H.I.H. (1990). Effect of certain compounds as bird repellent to protect field crops under different conditions. Zagazig J. Agric. Res., 17 (5B): 1701-1707.

El-Deeb, H.I.H. (1991). Bird damage to some ripening field crops, under different conditions in Egypt. Zagazig. J. A Agric., Res., 18 (3): 835 -481.

El-Sherbiny, A.H., A.M. Omar, A.G. El-Sisi and M.A.A. Hewady (1994). Natural botanical extracts as repellents for the house sparrow, Passer domesticus II- Efficacy under rice field conditions. Ann. Agric. Sci. Moshtohor, 32 (2): 1053-1064.

Hess, J.B. and W.M. Britton (1997). Effects of dietary magnesium excess in white leghorn hens. Poult. Sci., 76 : 703-710.

Issa, M.A. and M.I.A. El-Bakhshawngi (2018). An estimation of bird damage on some field, vegetable and fruit crops at Sharkia Governorate, Egypt. Zagazig J. Agric. Res., 45 (4): $1273-1281$.

Kale, M.A., N. Dudhe, R. Kasambe and P. Bhattacharya (2014). Crop depredation by birds in Deccan Plateau, India. Int. J. Biodiversity Volume (2014), Article ID 947683, 8 pages, http:// dx.doi.org/10.1155/ 2014/947683.

Kassa, H. and W.B. Jackson (1979). Mesurol as a bird repellent on grape in Ohio. Proceeding. Eighth Bowling Green Bird Control Seminar, Bowling Green, Ohio, 1981.

Khattab, M.M. (1993). Biological, ecological and toxicological studies on harmful birds of agriculture in Sharkia Governorate. M.Sc. Thesis, Fac. Agric., Al-Azhar Univ., 199.

Langyintuo, A.S., D.J., Lowenberg, M. Faye, D. Lambert, G. Ibro, B. Moussa, A. Kergna, S. Kushwaha, S. Musa and G. Ntoukam (2003). Cowpea supply and demand in West Africa. Field Crops Res., 82: 215-231.

Niner, M.D., G.M. Linz and M.E. Clark (2015). Evaluation of 9,10-anthraquinone application to pre-seed set sunflowers for repelling blackbirds. Hum-Wildl Interact 9: 4-13.

Pereira, D.M., P. Valentão, J.A. Pereira and P.B. Andrade (2009). Phenolics: from chemistry to biology. J. Molecules, 14: 2202 - 2211. 
Poche, R.M., M.U. Mian, M.E. Hoqie and P. Sultana (1982). Rodent damage and burrowing characteristics in Bangladesh wheat fields. J. Will. Manage, 46: 139- 147.

Rizvi, S.W.A., A. Pervez and S.M. Ahmed (2002). Evaluation of methiocarb 50\%WP as a taste repellent against the house sparrow (Passer domesticus L.). Turkish J. Zool., 26: 131-135.

Schafer, E.W. Jr. (1991). Bird Control Chemicals-Nature, modes of action, and toxicity. In: Handbook of Pest Management in Agriculture, Pimental, D.(ed.) CRC Press,
Boca Raton, Florida, (vol. 2), $2^{\text {nd }}$ Ed., 599610.

Werner, S.J., S.T. DeLiberto, A.M. Mangan, S.E. Petti, J.W. Ellis and J.C. Carlson (2015). Anthraquinone-based repellent for horned larks, great-tailed grackles, American crows and the protection of California's specialty crops. Crop Prot., 72: 158-162.

York, D.L., J.L. Cummings, R.M. Engeman and J.E.Jr. Davis (2000). Evaluation of flight control and mesurol as repellents to reduce horned lark (Eremophila alpestris) damage to lettuce seedlings. Crop Prot., 19: 201-203.

\section{التأثير الطارد لبعض المركبات الكيميائية علي مهاجمة الطيور البرية للقمح واللوبيا تحت الظروف الحقلية}

محمد عبدالله عيسى ـ محمد إبراهيم عبد العظيم البخثونجي ـ محمد حسن عصام الدين لقمة

$$
\text { معهد بحوث وقاية النباتات - مركز البحوث الزئر اعية ـ الدقي - جيزة - مصر }
$$

تم دراسة التأثير الطارد لكل من مركبي التوكم والفي بي سكد علي الطيور البرية التي تهاجم محصولي القمح و اللوبيا

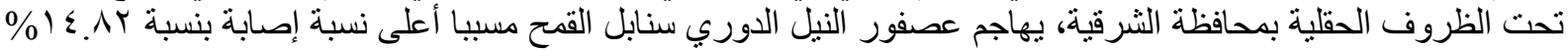

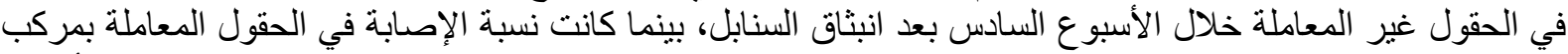

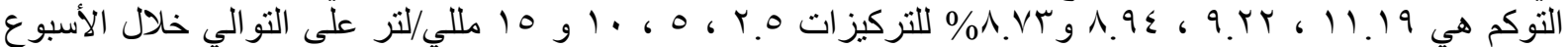

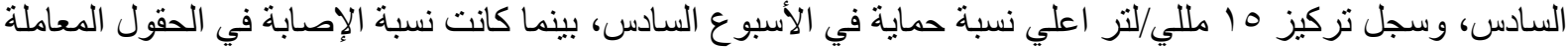

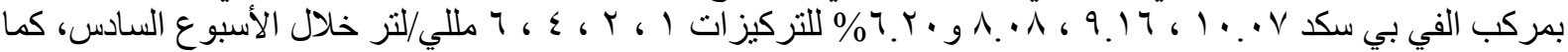

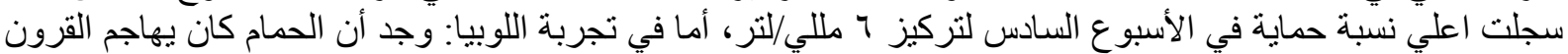

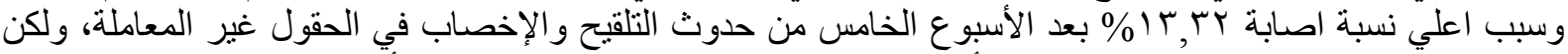

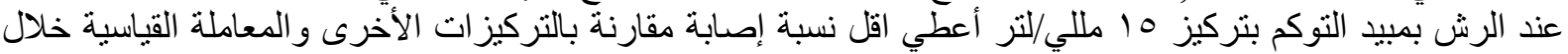

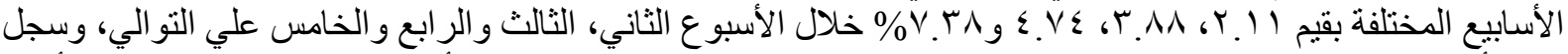

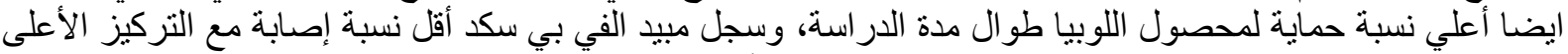

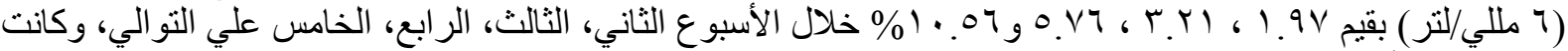

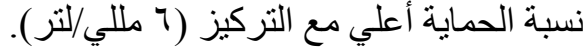

